\title{
IDENTIFIKASI MORFOMETRIKS DAN JARAK GENETIK AYAM KAMPUNG DI LABUHANBATU SELATAN
}

\author{
Identification of Genetic Distance Morfometriks And Chicken Domesticated in \\ Labuhanbatu Selatan
}

\author{
Nelli Awari Rangkuti ${ }^{1}$, Hamdan ${ }^{2}$ dan, Armyn Hakim Daulay ${ }^{2}$ \\ 1. Mahasiswa Program Studi Peternakan Fakultas Pertanian Universitas SumateraUtara \\ 2. Staf Pengajar Program Studi Peternakan Fakultas Pertanian Universitas Sumatera Utara
}

\begin{abstract}
This study aims to identify the size and shape of the body and the genetic distance ayam kampung throughout South Labuhanbatu Subdistrict, North Sumatra. Ayam kampung as the samples are 930 males and 930 females, the sample used every district the Sungai Kanan tails 357, 377 Torgamba tails, tails 370 Kota Pinang, Silangkitang 379 tails, and the tails 379 Kampung Rakyat. Morphometric analyzed using discriminant analysis, canonical, Mahalonobis with the help of SAS ver. 6:12 Discrim Proc procedures and genetic distances were analyzed using the software MEGA2. The results showed Torgamba ayam kampung in the district are phenotypically different from that in the district ayam kmpung sungai kanan, Silangkitang subdistrict, subdistrict kota Pinang and kampung rakyat where the number of larger body size than other ayam kampung. The results of the first canonical analysis showed distinctive body size male ayam kampung is Long Neck and Chest circumference, while the second canonical male ayam kampung is half and Long Term Combs. The first canonical ayam kampung wings and the females are Width Length Bodies, whereas the second canonical female ayam kampung is Long Term Part and Combs. Similarity values and the mixture is highest among sub-districts in the district Torgamba ayam kampung $58.82 \%$ in male and $63.35 \%$ in female ayam kampung. Genetic distance ayam kampung is highest in the district and sub-district Torgamba Sungai Kanan is 2.73670 and 3.47529 males in betin. The conclusion of this study is the ayam kampung with the same production goals demonstrate the value of a mix between clumps of relatively high and relatively the same body size.
\end{abstract}

Keywords: Ayam Kampung, Morphometric, Genetic Distance.

\begin{abstract}
ABSTRAK
Penelitian ini bertujuan untuk mengidentifikasi ukuran dan bentuk tubuh serta jarak genetik ayam kampung di seluruh Kecamatan Kabupaten Labuhanbatu Selatan, Sumatera Utara. Ayam kampung sebagai sampel penelitian sebanyak 930 jantan dan 930 betina, sampel yang digunakan setiap kecamatan yaitu Sungai Kanan 357 ekor, Torgamba 377 ekor, Kota Pinang 370 ekor, Silangkitang 379 ekor, dan Kampung Rakyat 379 ekor. Morfometrik dianalisis menggunakan Analisis Diskriminan, Kanonikal, Mahalonobis dengan bantuan program SAS ver. 6.12 dengan prosedur Proc Discrim dan jarak genetik dianalisis menggunakan perangkat lunak MEGA2. Hasil penelitian menunjukkan ayam kampung di kecamatan Torgamba secara fenotipik berbeda dengan ayam kampung yang di kecamatan Sungai Kanan, kecamatan Silangkitang, kecamatan Kota Pinang dan kecamatan Kampung Rakyat dimana jumlah ukuran tubuh lebih besar dibandingkan ayam kampung lain. Hasil analisis kanonik pertama menunjukkan pembeda ukuran tubuh ayam kampung jantan adalah Panjang Leher dan Lingkar Dada, sedangkan kanonik kedua ayam kampung jantan adalah Panjang Paruh dan Panjang Jengger. Kanonik pertama ayam kampung betina adalah Lebar Sayap dan Panjang Badan, sedangkan pada kanonik kedua ayam kampung betina adalah Panjang Paruh dan Panjang Jengger. Nilai kesamaan dan campuran dalam antar kecamatan tertinggi terdapat di kecamatan Torgamba $58,82 \%$ pada ayam kampung jantan dan $63,35 \%$ pada ayam kampung betina. Jarak genetik ayam kampung tertinggi terdapat di kecamatan Torgamba dan kecamatan Sungai Kanan yaitu 2,73670 pada jantan dan 3,47529 pada betina. Kesimpulan dari penelitian ini adalah ayam kampung dengan tujuan produksi yang sama menunjukkan nilai campuran antar rumpun relatif tinggi dan ukuran tubuh yang relatif sama.
\end{abstract}

Kata kunci : ayam kampung, morfometrik, jarak genetic. 


\section{PENDAHULUAN}

Indonesia merupakan salah satu negara di dunia yang sangat kaya dengan sumber plasma nutfah, bila dibandingkan dengan sebagian besar negara-negara lain di dunia. Letak geografis Indonesia di antara dua benua dan dua samudera juga bentuk negara Indonesia yang memiliki lebih dari 17.000 pulau menjadikan Indonesia memiliki keanekaragaman flora dan fauna yang tinggi. Salah satu sumber genetik ternak lokal yang perlu dilestarikan adalah ayam. Saat ini, terdapat 31 rumpun ayam lokal Indonesia yang menyebar di seluruh pelosok Indonesia yang memiliki karakteristik morfologis khas berdasarkan daerah asal.

Upaya untuk mempertahankan ternak-ternak lokal di suatu daerah atau negara karena ternak-ternak tersebut telah begitu beradaptasi dengan keadaan lingkungan sendiri baik terhadap makanan yang bernilai gizi rendah maupun penyakit terutama di daerahtropis. Namun, inventarisasi terhadap potensi berbagai sumberdaya genetik ternak, distribusi dan

performans trend perkembangan populasinya masih belum lengkap sehingga sangat sulit dilakukan kebijakan-kebijakan yang strategis khususnya arah dan program kerja manajemen pemanfaatan dan konservasi sumberdaya genetik ternak baik secara morfologis maupun genetik.

Ayam Kampung paling banyak menyebar di Indonesia. Ayam ini disukai masyarakat karena kualitas daging dan telur yang baik. Ayam Kampung banyak dipelihara secara tradisional atau ekstensif di pekarangan atau dibiarkan bebas (Nataamijaya, 2000) dan mudah ditemukan di desa-desa hampir di seluruh wilayah Indonesia (Sulandari dkk, 2007).

Ayam Kampung memiliki keragaman fenotip dan genotip yang cukup tinggi. Secara umum, ciri-ciri ayam Kampung adalah memiliki tubuh yang ramping, kaki panjang dan warna bulu beragam. Bobot badan dewasa ayam kampung adalah 1,5-1,8 kg pada jantan dan 1,0-1,4 kg pada betina (Sulandari dkk, 2007). Sistem pemeliharaan sangat mempengaruhi produksi telur ayam Kampung.

Ayam Kampung umumnya memiliki keunggulan dalam hal resistensi terhadap penyakit, resistensi terhadap panas serta memiliki kualitas daging dan telur yang lebih baik dibandingkan dengan ayam ras (Chen, Lee, Huang, dan Huang, 1993).

Ayam kampung juga memiliki beberapa kelemahan, antara lain adalah sulitnya memperoleh bibit yang baik dan produktifitasnya yang rendah, ditambah dengan adanya faktor penyakit musiman seperti ND (Newcastle Disease), sehingga dikhawatirkan populasi ayam kampung akan semakin menurun, bahkan ayam kampung yang mempunyai sifat-sifat spesifik tersebut akan punah. 
Mansjoer (1985) menyatakan bahwa ayam Kampung merupakan ayam asli Indonesia yang masih memiliki gen asli sebanyak lebih kurang 50\%. Adanya variasi genetik yang tinggi dari ayam Kampung menunjukan adanya potensi untuk dilakukannya perbaikan mutu genetik. Oleh karena itu diperlukan data dasar mengenai sifatsifat kualitatif dan kuantitatif ayam Kampung untuk mempertahankan kemurnian serta pelestarian sumber daya genetik ayam Kampung.

Upaya peningkatan produktivitas tidak cukup hanya dengan perbaikan pakan dan manajemen pemeliharaan, tetapi perlu dilakukan peningkatan mutu genetiknya dengan mempertahankan sifat-sifat khas ternak tersebut.

\title{
BAHAN DAN METODE PENELITIAN
}

\section{Lokasi dan Waktu Penelitian}

Lokasi penelitian di Labuhanbatu Selatan dengan lima Kecamatan yang merupakan asal ayam kampung yang diteliti dan dijadikan objek penelitiandi peternakan warga dari setiap Kecamatan. Penelitian ini dilaksanakan selama 3 bulan.

\section{Bahan}

Ayam kampung sebagai sampel penelitian sebanyak 50\% jantan dan betina $50 \%$ dari sampel seluruh kecamatan yang berada di Kabupaten Labuhanbatu Selatan dengan ketentuan perhitungan pada tabel interval keyakinan penelitian pada metode Cohen Manion dan Morisson.

Adapun data yang akan diukur adalah sebanyak 60\% dari populasi dan dikonfersikan melalui tabel interval keyakinan pada penelitian adalah 95\% dengan alpha 0,1. Sampel yang digunakan setiap kecamatan yaitu Sungai Kanan 357 ekor, Torgamba 377 ekor, Kota Pinang 370 ekor, Silangkitang 379 ekor, dan Kampung Rakyat 379 ekor.

\begin{abstract}
Alat
Jangka sorong dan pita ukur berskala terkecil $1 \mathrm{~mm}$ sebagai alat pengukur, alat tulis sebagai mencatat hasil pengukuran tubuh, kamera sebagai alat dokumentasi, dan satu unit komputer yang dilengkapi program Statistics Analytical System (SAS ver. 6.12) untuk alat bantu pengolahan data.
\end{abstract}

\section{Metode Penelitian}

Setiap organ tubuh bagian luar diukur mulai daripanjang badan, panjang/tinggi leher, panjang sayap, lebar sayap, lingkar dada, panjang kepala, lebar kepala, panjang paruh, 
panjang jengger, tinggi jengger, panjang tulang tibia, panjang metatarsus, lingkar metatarsus, dan panjang jari terpanjang dari ayam kampung serta dilakukan pengamatan langsung terhadap sifat kualitatif dan di tentukan jarak genetiknya sesuai dengan objek yang ada. Pengukuran ternak dilaksanakan di kandang ternak untuk memudahkan dalam pengendalian ternak dan dapat dibantu pengawasannya oleh peternak (Romdhani, 2004).

\section{Parameter Penelitian}

a. Jarak genetik ayam kampung dihitung menggunakan program SAS ver. 6.12.

b. Morfometrik organ tubuh luar ayam kampung.

Pengukuran ukuran linear permukaan tubuh ternak sebagai sifat kuantitatif dapat digunakan dalam seleksi (Mulliono, 1996). Dijelaskan lebih lanjut bahwa pengukuran ukuran linear permukaan tubuh tersebut dilakukan untuk memperoleh perbedaan ukuran-ukuran tubuh dalam populasi ternak. Perbedaan ukuran tubuh pada saat dewasa kelamin dapat memberikan penampakan yang berbeda pada setiap ternak.

Bagian-bagian tubuh luar yang akan diukur adalah dari kepala hingga bagian tarsometatarsus hingga kaki ayam kampung. Seluruh ukuran tubuh diukur dalam satuan cm dan bagian tubuh yang diukur antara lain:

1. Panjang badan (PB) dimulai dari pangkal leher hingga bagian belakang ayam (tulang pubis) yang diukur menggunakan pita ukur.

2. Panjang / tinggi leher (PL) dimulai dari pangkal kepala belakang hingga sudut antara tulang leher dan punggung (Scapula).

3. Panjang sayap (PS) diukur mulai dari pangkal sayap hingga ujung bagian sampai tulang metacarpus dan ujung tulang jari terpanjang pada sayap (Sisson dan Grossman, 1953).

4. Lebar sayap (LS) diukur mulai dai dari bagian atas sayap hingga bagian terbawah sayap (diukur bagian terlebar dari bentangan sayap).

5. Lingkar dada (LiD) diukur melingkar scapula menggunakan pita ukur.

6. Lebar dada (LeD) diukur dari kiri ke kanan bagian depan dada menggunakan pita ukur.

7. Panjang kepala (PK) diukur pada posisi tengah kepala dari atas paruh hingga pangkal kepala belakang dengan pita ukur.

8. Lebar kepala (LK) diukur dari posisi samping bagian kiri sampai kanan dengan menggunakan jangka sorong.

9. Panjang paruh (PP) diukur menggunakan pita ukur. 
10. Panjang jengger (PJ) diukur dari posisi depan hingga akhir bagian jengger menggunakan pita ukur (Nishida dkk, 1982).

11. Tinggi jengger (TJ) diukur dari pangkal jengger di atas kepala hingga bagian tertinggi jengger diukur menggunakan pita ukur (Nishida dkk, 1982).

12. Panjang tulang tibia (PtT) diukur menggunakan pita ukur (McLelland, 1990).

13. Panjang metatarsus (PM) diukur dari ujung tulang tibia hingga pangkal metatarsus bagian bawah diukur menggunakan pita ukur (Sisson dan Grossman, 1953).

14. Lingkar metatarsus (LM) diukur pada diameter menggunakan jangka sorong (Kurniawati, 2008)

15. Panjang jari terpanjang (JT) dari ayam kampung menggunakan pita ukur (Sisson dan Grossman, 1953).

\section{HASIL DAN PEMBAHASAN}

\section{Karakteristik Ukuran Tubuh Ayam Kampung}

Hasil penelitian perhitungan uji LSM (Last Squares Means) ayam kampung terdapat perbedaan dan persamaan ukuran tubuh yang diukur mulai dari panjang badan, panjang/tinggi leher, panjang sayap, lebar sayap, lingkar dada, lebar dada, panjang kepala, lebar kepala, panjang paruh, panjang jengger, tinggi jengger, panjang tulang tibia, panjang metatarsus, lingkar metatarsus, dan panjang jari terpanjang. Gambar ayam kampung yang diteliti dari beberapa kecamatan di Labuhanbatu Selatan, ditampilkam pada Gambar 1-5.
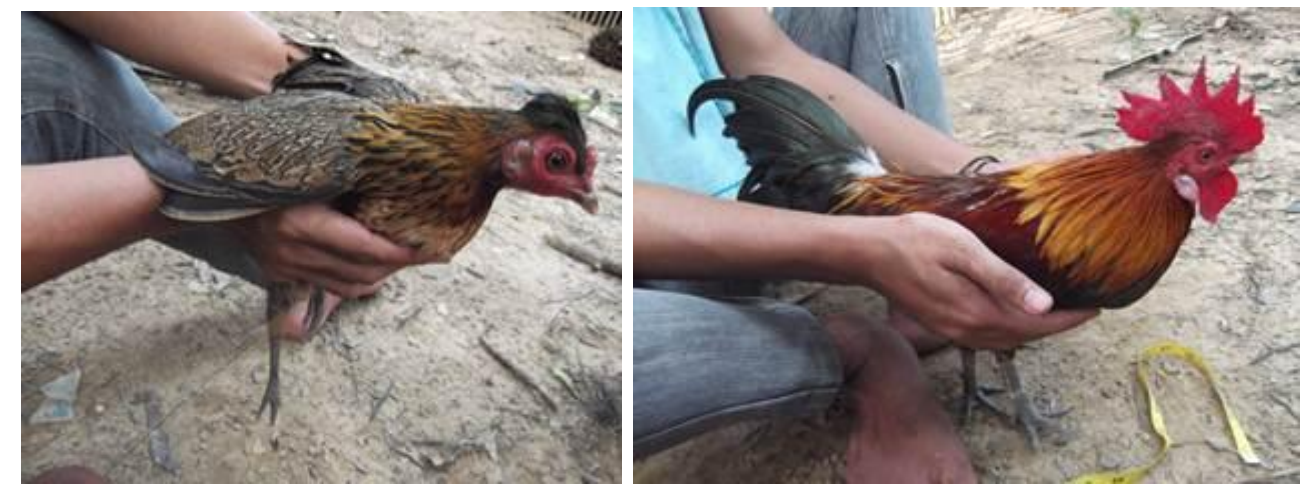

Gambar 1: ayam kampung betina dan ayam kampung jantan di kecamatan Sungai Kanan 

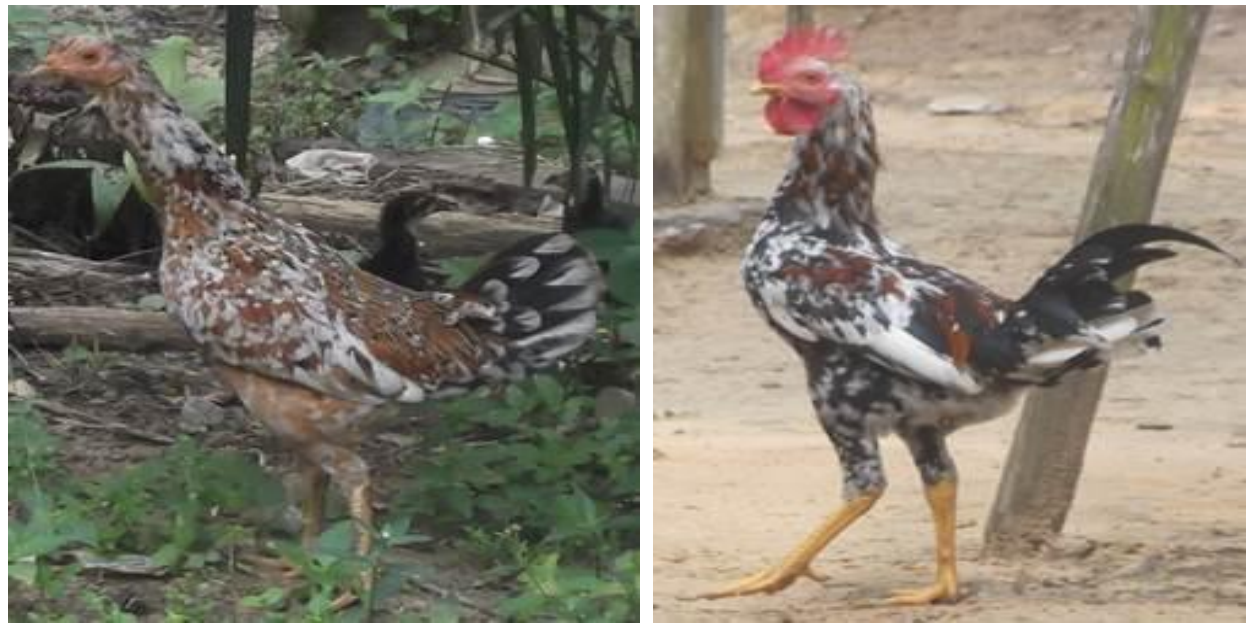

Gambar 2: ayam kampung betina dan ayam kampung jantan di kecamatan Kampung Rakyat
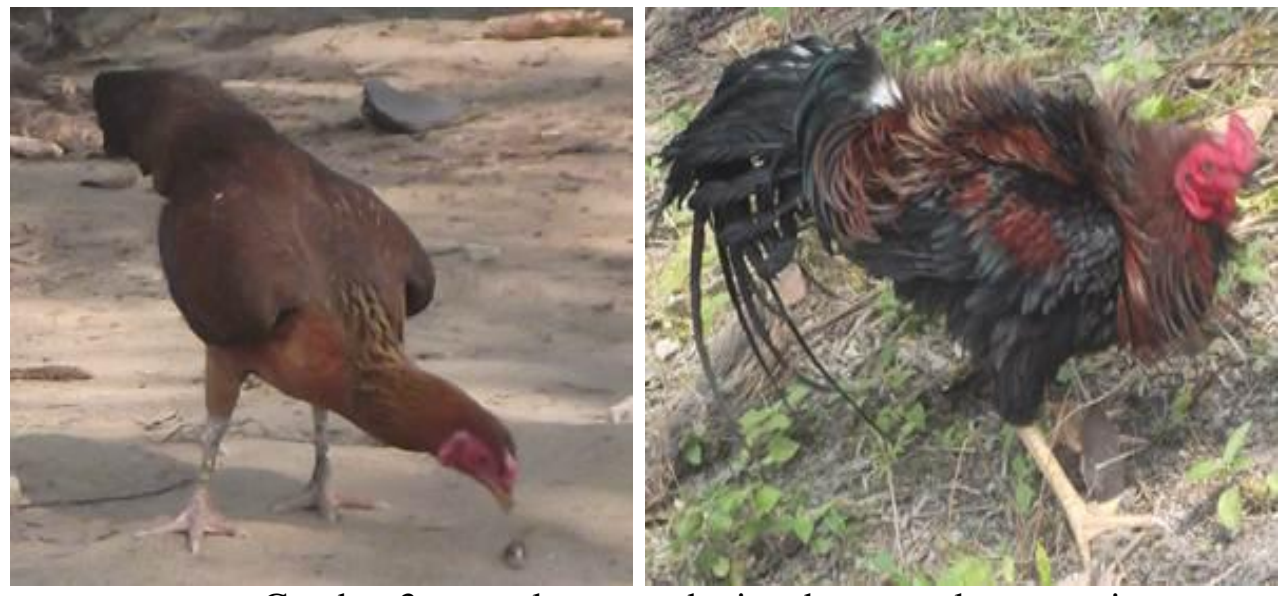

Gambar 3: ayam kampung betina dan ayam kampung jantan di kecamatan Togamba.
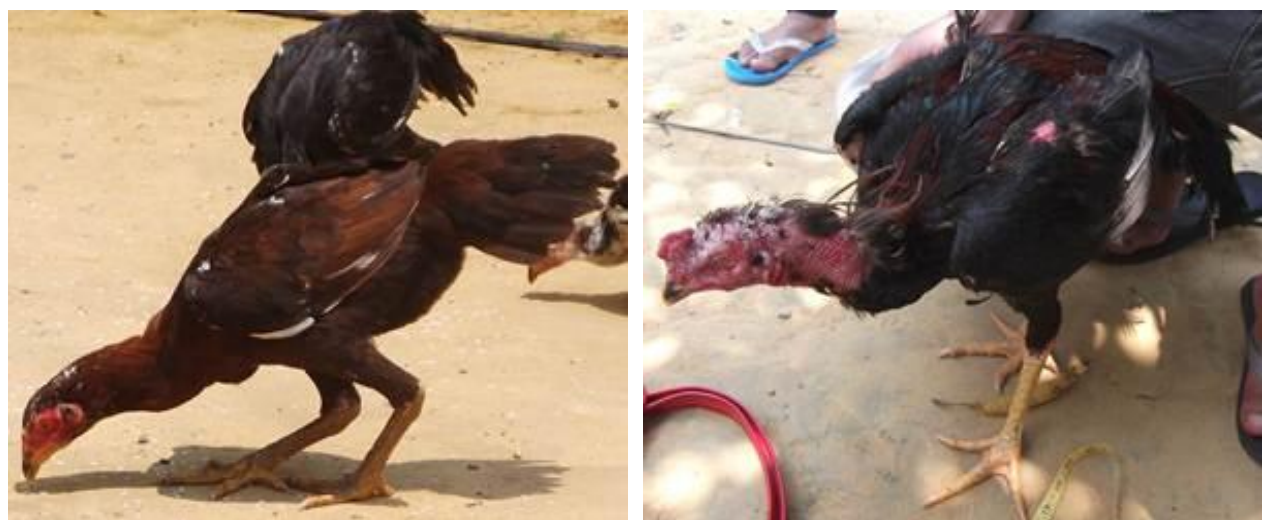

Gambar 4: ayam kampung betina dan ayam kampung jantan di kecamatan Silangkitang. 

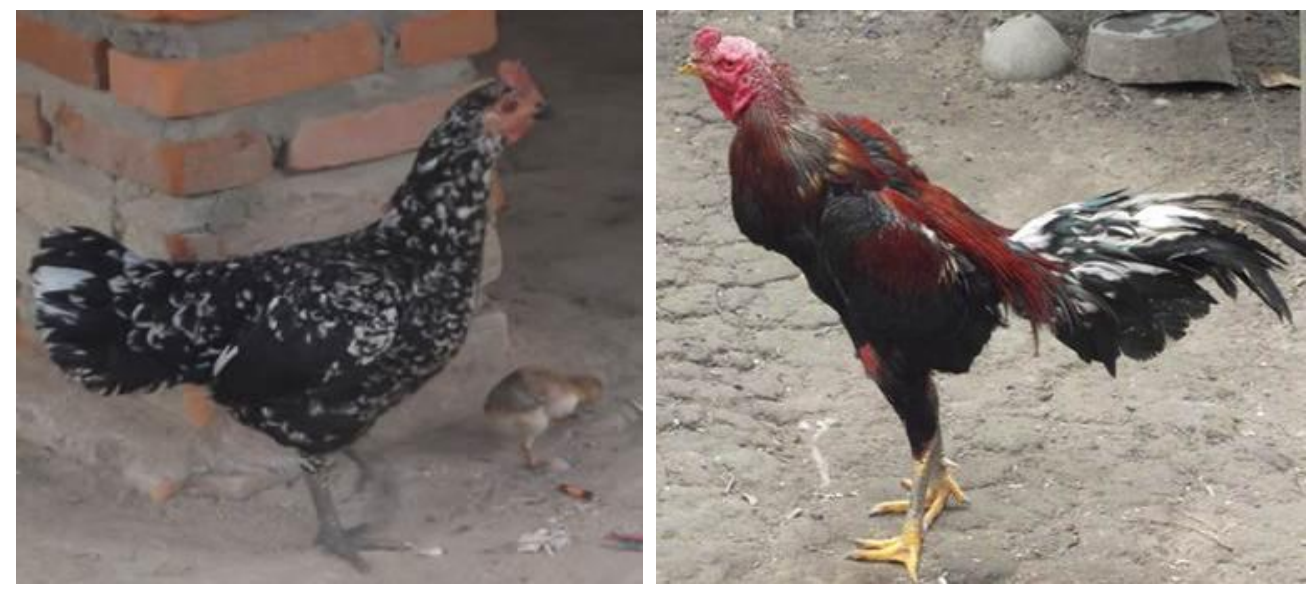

Gambar 5: ayam kampung betina dan ayam kampung jantan di kecamatan Kota Pinang

Secara umum rataan ukuran tubuh ayam kampung jantan yang paling besar terdapat pada kecamatan Torgamba (Tabel 1) yaitu 24,98 \pm 4,081 panjang badan, 10,48 \pm 2.204 panjang leher, $19.51 \pm 3,226$ panjang sayap, 20,70 \pm 2,420 lebar sayap, 33,15 \pm 5,120 lingkar dada, 5,05 \pm 0,967 panjang kepala, 2,66 \pm 0,608 panjang paruh, 13,57 $\pm 2,078$ panjang tulang tibia, 9,40 $\pm 1,819$ panjang metatarsus, 1,37 \pm 0,318 lingkar metatarsus, 6,63 $\pm 0,822$ panjang jari terpanjang, sedangkan lebar dada 13,45 \pm 2,132 yang paling besar terdapat di kecamatan Kampung Rakyat, lebar kepala 3,45 \pm 0,544 paling besar di kecamatan Silangkitang, panjang jengger 3,45 $\pm 2,150$ paling besar di kecamatan Sungai Kanan, dan tinggi jengger 1,89 \pm 1,801 paling besar terdapat di kecamatan Kota Pinang.

Rataan ukuran tubuh ayam kampung jantan yang paling kecil terdapat kecamatan Sungai Kanan 22,40 \pm 4,034 panjang badan, 8,36 \pm 2,364 panjang leher, 17,85 \pm 3,183 panjang sayap18,99 \pm 2,132 lebar sayap, 29,19 \pm 5,112 lingkar dada, 13,03 \pm 2,356 lebar dada, 4,51 $\pm 0,807$ panjang kepala, 3,28 \pm 0,534 lebar kepala, 12,11 $\pm 2,849$ panjang tulang tibia, 8,26 \pm 2,072 panjang metatarsus, 1,18 \pm 0,286 lingkar metatarsus, 6,36 $\pm 0,972$ panjang jari terpanjang, sedangkan panjang paruh 2,39 \pm 0,494 di kecamatan. Kampung Rakyat, panjang jengger $2,96 \pm 1,940$ dan tinggi jengger $1,52 \pm 1,113$ paling kecil di kecamatan Silangkitang. 
Tabel 1. Rataan ukuran tubuh ayam kampung jantan

\begin{tabular}{|c|c|c|c|c|c|}
\hline \multirow[t]{2}{*}{ Parameter } & \multicolumn{5}{|c|}{ Kecamatan } \\
\hline & $\begin{array}{c}\text { Sungai Kanan } \\
(\mathrm{cm})\end{array}$ & $\begin{array}{c}\text { Kampung } \\
\text { Rakyat }(\mathbf{c m})\end{array}$ & $\begin{array}{c}\text { Torgamba } \\
(\mathbf{c m})\end{array}$ & $\begin{array}{l}\text { Silangkitang } \\
(\mathbf{c m})\end{array}$ & $\begin{array}{c}\text { Kota Pinang } \\
(\mathbf{c m})\end{array}$ \\
\hline Panjang & $22,40^{C} \pm 4,034$ & $23,53^{\mathrm{B}} \pm 4,073$ & $24,98^{\mathrm{A}} \pm 4,081$ & $23,69^{\mathrm{B}} \pm 5,991$ & $23,62^{\mathrm{B}} \pm 4,294$ \\
\hline \multirow[t]{2}{*}{ Badan } & $\mathrm{n}=178$ & $\mathrm{n}=190$ & $\mathrm{n}=187$ & $\mathrm{n}=189$ & $\mathrm{n}=186$ \\
\hline & kk $(18,00 \%)$ & kk $(17,30 \%)$ & kk $(16,33 \%)$ & $\mathrm{kk}(25,38 \%)$ & kk $(18,17 \%)$ \\
\hline Panjang & $8,36^{\mathrm{C}} \pm 2,364$ & $9,14^{\mathrm{B}} \pm 2,393$ & $10,48^{\mathrm{A}} \pm 2.204$ & $9,01^{\mathrm{B}} \pm 2,475$ & $9,19^{\mathrm{B}} \pm 2,462$ \\
\hline \multirow[t]{2}{*}{ Leher } & $\mathrm{n}=178$ & $\mathrm{n}=190$ & $\mathrm{n}=187$ & $\mathrm{n}=189$ & $\mathrm{n}=186$ \\
\hline & $\mathrm{kk}(28,27 \%)$ & kk $(26,18 \%)$ & kk $(21,03 \%)$ & kk $(27,46 \%)$ & $\mathrm{kk}(26,78 \%)$ \\
\hline Panjang & $17,85^{\mathrm{C}} \pm 3,183$ & $18,57^{\mathrm{B}} \pm 3,259$ & $19.51^{\mathrm{A}} \pm 3,226$ & $18,59^{\mathrm{B}} \pm 3,254$ & $18,60^{\mathrm{B}} \pm 3,291$ \\
\hline \multirow[t]{2}{*}{ Sayap } & $\mathrm{n}=178$ & $\mathrm{n}=190$ & $\mathrm{n}=187$ & $\mathrm{n}=189$ & $\mathrm{n}=186$ \\
\hline & kk $(17,83 \%)$ & kk $(17,54 \%)$ & kk $(17,53 \%)$ & kk $(17,50 \%)$ & kk $(17,69 \%)$ \\
\hline Lebar & $18,99^{\mathrm{B}} \pm 2,132$ & $19,31^{\mathrm{B}} \pm 2,445$ & $20,70^{\mathrm{A}} \pm 2,420$ & $19,34^{\mathrm{B}} \pm 2,686$ & $19,48^{\mathrm{B}} \pm 2,469$ \\
\hline \multirow[t]{2}{*}{ Sayap } & $\mathrm{n}=178$ & $\mathrm{n}=190$ & $\mathrm{n}=187$ & $\mathrm{n}=189$ & $\mathrm{n}=186$ \\
\hline & kk $(11,22 \%)$ & $\mathrm{kk}(12,66 \%)$ & kk $(11,69 \%)$ & kk $(13,88 \%)$ & kk $(12,67 \%)$ \\
\hline Lingkar & $29,19^{\mathrm{C}} \pm 5,112$ & $30,36^{\mathrm{B}} \pm 5,088$ & $33,15^{\mathrm{A}} \pm 5,120$ & $30,44^{\mathrm{B}} \pm 5,214$ & $30,60^{\mathrm{B}} \pm 5,041$ \\
\hline \multirow[t]{2}{*}{ Dada } & $\mathrm{n}=178$ & $\mathrm{n}=190$ & $\mathrm{n}=187$ & $\mathrm{n}=189$ & $\mathrm{n}=186$ \\
\hline & kk $(17,51 \%)$ & kk $(16,75 \%)$ & kk $(15,44 \%)$ & kk $(17,12 \%)$ & kk $(18,08 \%)$ \\
\hline \multirow[t]{3}{*}{ Lebar Dada } & $13,03^{\mathrm{AB}} \pm 2,356$ & $13,45^{\AA} \pm 2,132$ & $12,83^{\mathrm{B}} \pm 1,785$ & $13,20^{\mathrm{AB}} \pm 2,215$ & $13,40^{\AA} \pm 2,139$ \\
\hline & $\mathrm{n}=178$ & $\mathrm{n}=190$ & $\mathrm{n}=187$ & $\mathrm{n}=189$ & $\mathrm{n}=186$ \\
\hline & $\mathrm{kk}(18,08 \% \mathrm{a})$ & $\operatorname{kk}(15,85 \%)$ & kk $(13,91 \%)$ & $\mathrm{kk}(16,78 \%)$ & $\mathrm{kk}(15,96 \%)$ \\
\hline Panjang & $4,51^{\mathrm{B}} \pm 0,807$ & $4,67^{\mathrm{B}} \pm 0,988$ & $5,05^{\mathrm{A}} \pm 0,967$ & $4,62^{\mathrm{B}} \pm 0,856$ & $4,70^{\mathrm{B}} \pm 0,866$ \\
\hline \multirow[t]{2}{*}{ Kepala } & $\mathrm{n}=178$ & $\mathrm{n}=190$ & $\mathrm{n}=187$ & $\mathrm{n}=189$ & $\mathrm{n}=186$ \\
\hline & $\mathrm{kk}(17,89 \%)$ & $\mathrm{kk}(21,15 \%)$ & kk $(19,14 \%)$ & $\mathrm{kk}(18,52 \%)$ & $\mathrm{kk}(18,42 \%)$ \\
\hline Lebar & $3,28^{\mathrm{B}} \pm 0,534$ & $3,42^{\mathrm{A}} \pm 0,536$ & $3,43^{A} \pm 0,533$ & $3,45^{\mathrm{A}} \pm 0,544$ & $3,43^{\mathrm{A}} \pm 0,598$ \\
\hline \multirow[t]{2}{*}{ Kepala } & $\mathrm{n}=178$ & $\mathrm{n}=190$ & $\mathrm{n}=187$ & $\mathrm{n}=189$ & $\mathrm{n}=186$ \\
\hline & $\mathrm{kk}(16,28 \%)$ & $\mathrm{kk}(15,67 \%)$ & kk $(15,53 \%)$ & $\mathrm{kk}(15,76 \%)$ & kk $(17,43 \%)$ \\
\hline Panjang & $2,50^{\mathrm{B}} \pm 0,466$ & $2,39^{\mathrm{B}} \pm 0,494$ & $2,66^{\mathrm{A}} \pm 0,608$ & $2,41^{\mathrm{B}} \pm 0,627$ & $2,42^{\mathrm{B}} \pm 0,607$ \\
\hline \multirow[t]{2}{*}{ Paruh } & $\mathrm{n}=178$ & $\mathrm{n}=190$ & $\mathrm{n}=187$ & $\mathrm{n}=189$ & $\mathrm{n}=186$ \\
\hline & kk $(18,56 \%)$ & kk $(20,66 \%)$ & kk $(22,85 \%)$ & kk $(26,01 \%)$ & kk $(25,08 \%)$ \\
\hline Panjang & $3,45^{\mathrm{A}} \pm 2,150$ & $3,08^{\mathrm{AB}} \pm 2,083$ & $3,26^{\mathrm{AB}} \pm 2,034$ & $2,96^{\mathrm{B}} \pm 1,940$ & $3,20^{\mathrm{AB}} \pm 2,201$ \\
\hline \multirow[t]{2}{*}{ Jengger } & $\mathrm{n}=178$ & $\mathrm{n}=190$ & $\mathrm{n}=187$ & $\mathrm{n}=189$ & $\mathrm{n}=186$ \\
\hline & $\mathrm{kk}(62,31 \%)$ & $\mathrm{kk}(67,62 \%)$ & $\mathrm{kk}(62,39 \%)$ & $\mathrm{kk}(65,54 \%)$ & $\mathrm{kk}(68,78 \%)$ \\
\hline Tinggi & $1,89^{\AA} \pm 1,455$ & $1,85^{\AA} \pm 4,046$ & $1,71^{\mathrm{A}} \pm 1,179$ & $1,52^{\AA} \pm 1,113$ & $1,89^{\AA} \pm 1,801$ \\
\hline \multirow[t]{2}{*}{ Jengger } & $\mathrm{n}=178$ & $\mathrm{n}=190$ & $\mathrm{n}=187$ & $\mathrm{n}=189$ & $\mathrm{n}=186$ \\
\hline & kk $(76,98 \%)$ & $\mathrm{kk}(218,70 \%)$ & $\mathrm{kk}(68,94 \%)$ & $\mathrm{kk}(73,22 \%)$ & kk $(95,29 \%)$ \\
\hline Panjang & $12,11^{\mathrm{B}} \pm 2,849$ & $12,63^{\mathrm{B}} \pm 2,503$ & $13,57^{\mathrm{A}} \pm 2,078$ & $12,54^{\mathrm{B}} \pm 2,725$ & $12,53^{\mathrm{B}} \pm 2,732$ \\
\hline \multirow[t]{2}{*}{ tulang Tibia } & $\mathrm{n}=178$ & $\mathrm{n}=190$ & $\mathrm{n}=187$ & $\mathrm{n}=189$ & $\mathrm{n}=186$ \\
\hline & $\mathrm{kk}(23,52 \%)$ & $\mathrm{kk}(19,81 \%)$ & $\mathrm{kk}(15,31 \%)$ & $\mathrm{kk}(21,73 \%)$ & $\mathrm{kk}(21,80 \%)$ \\
\hline Panjang & $8,26^{\mathrm{B}} \pm 2,072$ & $8,50^{\mathrm{B}} \pm 1,840$ & $9,40^{\mathrm{A}} \pm 1,819$ & $8,51^{\mathrm{B}} \pm 2,029$ & $8,35^{\mathrm{B}} \pm 1,855$ \\
\hline \multirow[t]{2}{*}{ Metatarsus } & $\mathrm{n}=178$ & $\mathrm{n}=190$ & $\mathrm{n}=187$ & $\mathrm{n}=189$ & $\mathrm{n}=186$ \\
\hline & $\mathrm{kk}(25,08 \%)$ & kk $(21,64 \%)$ & kk $(19,35 \%)$ & $\mathrm{v}(23,84 \%)$ & $\mathrm{kk}(22,21 \%)$ \\
\hline Lingkar & $1,18^{\mathrm{C}} \pm 0,286$ & $1,25^{\mathrm{BC}} \pm 0,264$ & $1,37^{\mathrm{A}} \pm 0,318$ & $1,24^{\mathrm{BC}} \pm 0,278$ & $1,26^{\mathrm{B}} \pm 0,319$ \\
\hline \multirow[t]{2}{*}{ Metatarsus } & $\mathrm{n}=178$ & $\mathrm{n}=190$ & $\mathrm{n}=187$ & $\mathrm{n}=189$ & $\mathrm{n}=186$ \\
\hline & $\mathrm{kk}(24,23 \%)$ & $\mathrm{kk}(21,12 \%)$ & $\mathrm{v}(23,21 \%)$ & $\mathrm{kk}(22,41 \%)$ & $\mathrm{kk}(25,31 \%)$ \\
\hline Panjang jari & $6,36^{\mathrm{A}} \pm 0,972$ & $6,61^{\mathrm{A}} \pm 0,809$ & $6,63^{\mathrm{B}} \pm 0,822$ & $6,56^{\mathrm{A}} \pm 0,804$ & $6,54^{\mathrm{A}} \pm 0,806$ \\
\hline \multirow[t]{2}{*}{ Terpanjang } & $\mathrm{n}=178$ & $\mathrm{n}=190$ & $\mathrm{n}=187$ & $\mathrm{n}=189$ & $\mathrm{n}=186$ \\
\hline & $\mathrm{kk}(15,28 \%)$ & $\mathrm{kk}(12,23 \%)$ & $\mathrm{kk}(12,39 \%)$ & $\mathrm{kk}(12,25 \%)$ & $\mathrm{kk}(12,32 \%)$ \\
\hline
\end{tabular}

Keterangan : $\mathrm{n}=$ jumlah ayam yang diamati angka dalam tanda kurung menyatakan koefisien keragaman.

Rataan ukuran tubuh ayam kampung betina secara umum yang paling besar terdapat pada kecamatan Torgamba dapat dilihat pada Tabel 2 diatas yaitu 22,85 $\pm 2,524$ panjang badan, 9,82 $\pm 2,148$ panjang leher, 17,84 $\pm 2,394$ panjang sayap, 19,92 $\pm 2,544$ lebar sayap, $30,86 \pm$ 4,656 lingkar dada, 4,43 $\pm 0,858$ panjang kepala, $2,37 \pm 0,521$ panjang paruh, 11,72 $\pm 1,858$ panjang tulang tibia, 7,85 $\pm 1,467$ panjang metatarsus, $1,15 \pm 0,275$ lingkar metatarsus, 6,06 \pm 0,596 panjang jari terpanjang, sedangkan lebar dada 12,49 $\pm 1,974$ yang 
paling besar terdapat di kecamatan Kampung Rakyat, lebar kepala 3,13 \pm 0,335 paling besar di kecamatan Kota Pinang, dan panjang jengger 1,95 \pm 1,056 paling besar di kecamatan Sungai Kanan.

Tabel 2. Rataan ukuran tubuh ayam kampung betina

\begin{tabular}{|c|c|c|c|c|c|}
\hline \multirow[t]{2}{*}{ Parameter } & \multicolumn{5}{|c|}{ Kecamatan } \\
\hline & $\begin{array}{l}\text { Sungai Kanan } \\
(\mathrm{cm})\end{array}$ & $\begin{array}{c}\text { Kampung } \\
\text { Rakyat (cm) }\end{array}$ & $\begin{array}{c}\text { Torgamba } \\
\text { (cm) }\end{array}$ & $\begin{array}{l}\text { Silangkitang } \\
(\mathbf{c m})\end{array}$ & $\begin{array}{l}\text { Kota Pinang } \\
\text { (cm) }\end{array}$ \\
\hline Panjang & $20,70^{\mathrm{B}} \pm 2,799$ & $21,14^{\mathrm{B}} \pm 2,983$ & $22,85^{\mathrm{A}} \pm 2,524$ & $21,28^{\mathrm{B}} \pm 2,875$ & $21,17^{\mathrm{B}} \pm 2,794$ \\
\hline \multirow[t]{2}{*}{ Badan } & $\mathrm{n}=179$ & $\mathrm{n}=189$ & $\mathrm{n}=191$ & $\mathrm{n}=187$ & $\mathrm{n}=184$ \\
\hline & $\mathrm{kk}(13,52 \%)$ & $\mathrm{kk}(14,11 \%)$ & $\mathrm{kk}(11,04 \%)$ & $\mathrm{kk}(13,51 \%)$ & $\mathrm{kk}(13,19 \%)$ \\
\hline Panjang & $8,10^{\mathrm{B}} \pm 2,555$ & $8,28^{\mathrm{B}} \pm 2,696$ & $9,82^{\mathrm{A}} \pm 2,148$ & $8,22^{\mathrm{B}} \pm 2,704$ & $8,26^{\mathrm{B}} \pm 2,748$ \\
\hline \multirow[t]{2}{*}{ Leher } & $\mathrm{n}=179$ & $\mathrm{n}=189$ & $\mathrm{n}=191$ & $\mathrm{n}=187$ & $\mathrm{n}=184$ \\
\hline & kk $(31,54 \%)$ & kk $(32,56 \%)$ & kk $(21,87 \%)$ & kk $(32,89 \%)$ & $\mathrm{kk}(33,26 \%)$ \\
\hline Panjang & $16,17^{\mathrm{B}} \pm 2,376$ & $16,39^{\mathrm{B}} \pm 2,538$ & $17,84^{\mathrm{A}} \pm 2,394$ & $16,65^{\mathrm{B}} \pm 2,611$ & $16,34^{\mathrm{B}} \pm 2,355$ \\
\hline \multirow[t]{2}{*}{ Sayap } & $\mathrm{n}=179$ & $\mathrm{n}=189$ & $\mathrm{n}=191$ & $\mathrm{n}=187$ & $\mathrm{n}=184$ \\
\hline & kk $(14,69 \%)$ & $\mathrm{kk}(15,48 \%)$ & kk $(13,41 \%)$ & kk $(15,68 \%)$ & kk $(14,41 \%)$ \\
\hline Lebar & $18,26^{\mathrm{B}} \pm 1,756$ & $18,35^{\mathrm{B}} \pm 1,906$ & $19,92^{\AA} \pm 2,544$ & $18,50^{\mathrm{B}} \pm 1,992$ & $18,45^{\mathrm{B}} \pm 2,026$ \\
\hline \multirow[t]{2}{*}{ Sayap } & $\mathrm{n}=179$ & $\mathrm{n}=189$ & $\mathrm{n}=191$ & $\mathrm{n}=187$ & $\mathrm{n}=184$ \\
\hline & kk $(9,61 \%)$ & kk $(10,38 \%)$ & kk $(12,77 \%)$ & kk $(10,76 \%)$ & kk $(11,98 \%)$ \\
\hline Lingkar & $27,74^{\mathrm{B}} \pm 4,537$ & $28,38^{\mathrm{B}} \pm 4,404$ & $30,86^{\mathrm{A}} \pm 4,656$ & $28,61^{\mathrm{B}} \pm 4,479$ & $28,48^{\mathrm{B}} \pm 4,393$ \\
\hline \multirow[t]{2}{*}{ Dada } & $\mathrm{n}=179$ & $\mathrm{n}=189$ & $\mathrm{n}=191$ & $\mathrm{n}=187$ & $\mathrm{n}=184$ \\
\hline & kk $(16,35 \%)$ & kk $(15,51 \%)$ & kk $(15,08 \%)$ & $\mathrm{kk}(15,65 \%)$ & kk $(15,42 \%)$ \\
\hline \multirow[t]{3}{*}{ Lebar Dada } & $112,48^{\AA} \pm 2,070$ & $12,49^{\AA} \pm 1,974$ & $11,86^{\mathrm{B}} \pm 1,433$ & $12,45^{\AA} \pm 1,909$ & $12,40^{\AA} \pm 1,783$ \\
\hline & $\mathrm{n}=179$ & $\mathrm{n}=189$ & $\mathrm{n}=191$ & $\mathrm{n}=187$ & $\mathrm{n}=184$ \\
\hline & $\mathrm{kk}(16,58 \% \mathrm{a})$ & $\operatorname{kk}(15,81 \%)$ & $\mathrm{kk}(12,08 \%)$ & $\mathrm{kk}(15,33 \%)$ & $\mathrm{kk}(14,37 \%)$ \\
\hline Panjang & $3,94^{\mathrm{B}} \pm 0,700$ & $4,02^{\mathrm{B}} \pm 0,683$ & $4,43^{\mathrm{A}} \pm 0,858$ & $4,06^{\mathrm{B}} \pm 0,717$ & $4,09^{\mathrm{B}} \pm 0,611$ \\
\hline \multirow[t]{2}{*}{ Kepala } & $\mathrm{n}=179$ & $\mathrm{n}=189$ & $\mathrm{n}=191$ & $\mathrm{n}=187$ & $\mathrm{n}=184$ \\
\hline & kk $(17,76 \%)$ & kk $(16,99 \%)$ & kk $(19,36 \%)$ & kk $(17,66 \%)$ & kk $(14,93 \%)$ \\
\hline Lebar & $3,03^{\mathrm{B}} \pm 0,461$ & $3,05^{\mathrm{AB}} \pm 0,410$ & $3,13^{\mathrm{A}} \pm 0,335$ & $3,10^{\mathrm{AB}} \pm 0,569$ & $3,43^{\mathrm{AB}} \pm 0,598$ \\
\hline \multirow[t]{2}{*}{ Kepala } & $\mathrm{n}=179$ & $\mathrm{n}=189$ & $\mathrm{n}=191$ & $\mathrm{n}=187$ & $\mathrm{n}=184$ \\
\hline & kk $(15,21 \%)$ & $\mathrm{kk}(13,44 \%)$ & kk $(10,70 \%)$ & $\mathrm{kk}(18,35 \%)$ & $\mathrm{kk}(17,43 \%)$ \\
\hline Panjang & $3,43^{\mathrm{AB}} \pm 0,598$ & $2,15^{\mathrm{B}} \pm 0,437$ & $2,37^{\mathrm{A}} \pm 0,521$ & $2,15^{\mathrm{B}} \pm 0,465$ & $2,16^{\mathrm{B}} \pm 0,448$ \\
\hline \multirow{2}{*}{ Paruh } & $\mathrm{n}=179$ & $\mathrm{n}=189$ & $\mathrm{n}=191$ & $\mathrm{n}=187$ & $\mathrm{n}=184$ \\
\hline & $\mathrm{kk}(19,45 \%)$ & $\mathrm{kk}(20,32 \%)$ & $\mathrm{kk}(21,98 \%)$ & $\mathrm{kk}(21,62 \%)$ & $\mathrm{kk}(20,74 \%)$ \\
\hline Panjang & $1,95^{\mathrm{A}} \pm 1,056$ & $1,55^{\mathrm{BC}} \pm 0,946$ & $1,72^{\mathrm{B}} \pm 0,986$ & $1,50^{\mathrm{C}} \pm 0,874$ & $1,64^{\mathrm{BC}} \pm 1,071$ \\
\hline \multirow[t]{2}{*}{ Jengger } & $\mathrm{n}=179$ & $\mathrm{n}=189$ & $\mathrm{n}=191$ & $\mathrm{n}=187$ & $\mathrm{n}=184$ \\
\hline & $\mathrm{kk}(54,15 \%)$ & $\mathrm{kk}(61,03 \%)$ & $\operatorname{kk}(57,32 \%)$ & $\mathrm{kk}(58,26 \%)$ & $\mathrm{kk}(65,30 \%)$ \\
\hline Tinggi & $0,99^{\AA} \pm 0,706$ & $0,74^{\mathrm{C}} \pm 0,558$ & $0,82^{\mathrm{ABC}} \pm 0,560$ & $0,76^{\mathrm{BC}} \pm 0,549$ & $0,92^{\mathrm{AB}} \pm 1,256$ \\
\hline \multirow[t]{2}{*}{ Jengger } & $\mathrm{n}=179$ & $\mathrm{n}=189$ & $\mathrm{n}=191$ & $\mathrm{n}=187$ & $\mathrm{n}=184$ \\
\hline & $\mathrm{kk}(70,31 \%)$ & kk $(75,40 \%)$ & kk $(68,29 \%)$ & $\mathrm{kk}(72,23 \%)$ & $\mathrm{kk}(136,52 \%)$ \\
\hline Panjang & $11,00^{\mathrm{B}} \pm 2,151$ & $11,16^{\mathrm{B}} \pm 2,136$ & $11,72^{\mathrm{A}} \pm 1,858$ & $11,03^{\mathrm{B}} \pm 2,235$ & $11,14^{\mathrm{B}} \pm 2,028$ \\
\hline \multirow[t]{2}{*}{ tulang Tibia } & $\mathrm{n}=179$ & $\mathrm{n}=189$ & $\mathrm{n}=191$ & $\mathrm{n}=187$ & $\mathrm{n}=184$ \\
\hline & $\mathrm{kk}(19,55 \%)$ & kk $(19,13 \%)$ & $\mathrm{kk}(15,85 \%)$ & $\mathrm{kk}(20,26 \%)$ & $\mathrm{kk}(18,20 \%)$ \\
\hline Panjang & $6,94^{\mathrm{B}} \pm 1,377$ & $7,02^{\mathrm{B}} \pm 1,339$ & $7,85^{\mathrm{A}} \pm 1,467$ & $7,06^{\mathrm{B}} \pm 1,503$ & $7,00^{\mathrm{B}} \pm 1,248$ \\
\hline \multirow[t]{2}{*}{ Metatarsus } & $\mathrm{n}=179$ & $\mathrm{n}=189$ & $n=191$ & $\mathrm{n}=187$ & $\mathrm{n}=184$ \\
\hline & kk $(19,84 \%)$ & kk $(19,07 \%)$ & kk $(18,68 \%)$ & $\mathrm{kk}(21,28 \%)$ & kk $(17,32 \%)$ \\
\hline Lingkar & $1,00^{\mathrm{B}} \pm 0,253$ & $1,02^{\mathrm{B}} \pm 0,245$ & $1,15^{\mathrm{A}} \pm 0,275$ & $1,03^{\mathrm{B}} \pm 0,261$ & $11,02^{\mathrm{B}} \pm 0,240$ \\
\hline \multirow[t]{2}{*}{ Metatarsus } & $\mathrm{n}=179$ & $\mathrm{n}=189$ & $\mathrm{n}=191$ & $\mathrm{n}=187$ & $\mathrm{n}=184$ \\
\hline & $\mathrm{kk} 25,3 \%)$ & kk $(24,01 \%)$ & $\mathrm{kk}(23,91 \%)$ & $\mathrm{kk}(25,33 \%)$ & $\mathrm{kk}(23,52 \%)$ \\
\hline & $5,65^{\mathrm{C}} \pm 0,725$ & $5,86^{\mathrm{B}} \pm 0,634$ & $6,06^{\mathrm{A}} \pm 0,596$ & $5,93^{\mathrm{B}} \pm 0,629$ & $5,88^{\mathrm{B}} \pm 0,598$ \\
\hline \multirow[t]{2}{*}{ Terpanjang } & $\mathrm{n}=179$ & $\mathrm{n}=189$ & $\mathrm{n}=191$ & $\mathrm{n}=187$ & $\mathrm{n}=184$ \\
\hline & $\mathrm{kk}(12,83 \%)$ & $\mathrm{kk}(10,81 \%)$ & kk $(9,83 \%)$ & $\mathrm{kk}(10,60 \%)$ & kk $(10,17 \%)$ \\
\hline
\end{tabular}

Keterangan $: \mathrm{n}=$ jumlah ayam yang diamati angka dalam tanda kurung menyatakan koefisien keragaman.

Secara umum rataan ukuran tubuh ayam kampung betina paling kecil terdapat kecamatan Sungai Kanan 8,10 \pm 2,555 panjang leher, 17,85 \pm 3,183 panjang sayap18,99 \pm 2,132 lebar sayap, 29,19 \pm 5,112 lingkar dada, 3,94 \pm 0,700 panjang kepala, 3,03 \pm 0,461 lebar kepala, 11,00 \pm 2,151 panjang tulang tibia, 6,94 \pm 1,377 panjang metatarsus, 1,00 \pm 
0,253 lingkar metatarsus, 5,65 \pm 0,725 panjang jari terpanjang, sedangkan panjang badan 21,14 $\pm 2,983$, panjang paruh 2,15 \pm 0,437, di kecamatan Kampung Rakyat, lebar dada 11,86 $\pm 1,433$ kecamatan. Torgamba, dan panjang jengger 1,50 $\pm 0,874$ paling kecil di kecamatan Silangkitang. Karakteristik ukuran tubuh ayam kampung (Tabel 3) keseluruhan di Kabupaten Labuhanbatu Selatan dijelaskan pada sub bab dibawah ini.

Tabel 3. Karakteristik ukuran tubuh ayam kampung keseluruhan di Labuhanbatu Selatan

\begin{tabular}{|c|c|c|}
\hline Parameter & Jantan $(\mathbf{c m})$ & Betina $(\mathbf{c m})$ \\
\hline \multirow[t]{2}{*}{ Panjang Badan } & $23,66 \pm 4,628 ; n=930$ & $21,44 \pm 2,890 ; n=930$ \\
\hline & kk $(19,56 \%)$ & $\operatorname{kk}(13,47 \%)$ \\
\hline \multirow[t]{2}{*}{ Panjang Leher } & $9,25 \pm 2,473 ; n=930$ & $8,55 \pm 2,654 ; n=930$ \\
\hline & $\mathrm{kk}(26,73 \%)$ & $\operatorname{kk}(31,04 \%)$ \\
\hline \multirow[t]{2}{*}{ Panjang Sayap } & $18,64 \pm 3,278 ; n=930$ & $16,69 \pm 2,526 ; n=930$ \\
\hline & $\mathrm{kk}(17,58 \%)$ & $\mathrm{kk}(15,13 \%)$ \\
\hline \multirow[t]{2}{*}{ Lebar Sayap } & $19,57 \pm 2,507 ; n=930$ & $18,70 \pm 2,154 ; n=930$ \\
\hline & $\mathrm{kk}(12,81 \%)$ & $\mathrm{kk}(11,51 \%)$ \\
\hline \multirow[t]{2}{*}{ Lingkar Dada } & $30,77 \pm 5,268 ; n=930$ & $28,83 \pm 4,612 ; n=930$ \\
\hline & $\mathrm{kk}(17,12 \%)$ & $\mathrm{kk}(15,99 \%)$ \\
\hline \multirow[t]{2}{*}{ Lebar Dada } & $13,19 \pm 2,138 ; n=930$ & $12,33 \pm 1,856 ; n=930$ \\
\hline & $\mathrm{kk}(16,20 \%)$ & $\mathrm{kk}(15,05 \%)$ \\
\hline \multirow[t]{2}{*}{ Panjang Kepala } & $4,71 \pm 0,917 ; n=930$ & $4,11 \pm 0,738 ; n=930$ \\
\hline & $\operatorname{kk}(19,46 \%)$ & $\mathrm{kk}(17,95 \%)$ \\
\hline \multirow[t]{2}{*}{ Lebar Kepala } & $3,40 \pm 0,552 ; n=930$ & $3,07 \pm 0,440 ; \mathrm{n}=930$ \\
\hline & $\mathrm{kk}(16,23 \%)$ & $\operatorname{kk}(14,33 \%)$ \\
\hline \multirow[t]{2}{*}{ Panjang Paruh } & $2,47 \pm 0,573 ; n=930$ & $2,24 \pm 0,479 ; n=930$ \\
\hline & $\operatorname{kk}(23,19 \%)$ & $\operatorname{kk}(21,38 \%)$ \\
\hline \multirow[t]{2}{*}{ Panjang Jengger } & $3,18 \pm 2,079 ; n=930$ & $1.67 \pm 0,998 ; n=930$ \\
\hline & $\mathrm{kk}(65,37 \%)$ & kk $(59,76 \%)$ \\
\hline \multirow[t]{2}{*}{ Tinggi Jengger } & $1,77 \pm 2,219 ; n=930$ & $0.84 \pm 0,776 ; n=930$ \\
\hline & kk 79,76\%) & kk $(92,38 \%)$ \\
\hline \multirow[t]{2}{*}{ Panjang tulang Tibia } & $12,69 \pm 2,626 ; n=930$ & $11,21 \pm 2,097 ; n=930$ \\
\hline & kk $(20,69 \%)$ & $\mathrm{kk}(18,70 \%)$ \\
\hline \multirow[t]{2}{*}{ Panjang Metatarsus } & $8,61 \pm 1,964 ; n=930$ & $7,18 \pm 1,429 ; n=930$ \\
\hline & $\operatorname{kk}(22,81 \%)$ & kk $(19,90 \%)$ \\
\hline \multirow[t]{2}{*}{ Lingkar Metatarsus } & $1,26 \pm 0,299 ; n=930$ & $1,05 \pm 0,261 ; \mathrm{n}=930$ \\
\hline & $\operatorname{kk}(23,73 \%)$ & $\mathrm{kk}(24,85 \%)$ \\
\hline \multirow[t]{2}{*}{ Panjang jari Terpanjang } & $6,54 \pm 0,847 ; n=930$ & $5,88 \pm 0,650 ; n=930$ \\
\hline & $\mathrm{kk}(12,95 \%)$ & $\mathrm{kk}(11,05 \%)$ \\
\hline
\end{tabular}

Keterangan $: \mathrm{n}=$ jumlah ayam yang diamati angka dalam tanda kurung menyatakan koefisien keragaman

\section{Panjang Badan}

Panjang badan (PB) dimulai dari bagian pangkal leher hingga bagian belakang ayam (tulang pubis) yang dapat di ukur menggunakan pita ukur, dari rataan setiap ukuran tubuh ayam kampung di beberapa Kecamatan berbeda di Kabupaten Labuhanbatu Selatan seperti yang terlihat di Tabel 3, panjang badan (PB) rataan pada jantan sebesar 23,66 4,628 cm dan pada betina sebesar $21,44 \pm 2,890 \mathrm{~cm}$. 


\section{Panjang Leher}

Panjang leher (PL) dimul;ai dari bagian pangkal kepala belakang hingga sudut antara tulang leher dan punggung (Scapula). Panjang leher (PL) rataan pada jantan 9,25 2,473 cm dan pada betina sebesar 8,55 $\pm 2,654 \mathrm{~cm}$ dari Tabel 3 dapat dilihat.

\section{Panjang Sayap}

Panjang sayap (PS) dimulai pangkal sayap hingga ujung bagian sampai tulang metacarpus dan ujung tulang jari terpanjang pada sayap. Dari Tabel 3 dapat dilihat panjang sayap (PS) rataan pada jantan 18,64 $\pm 3,278 \mathrm{~cm}$ dan pada betina 16,69 $\pm 2,526 \mathrm{~cm}$. Bila dibandingkan dengan penelitian Sisson dan Grossman (1953) dengan rataan panjang sayap (PS) 21,84 $\pm 1,447 \mathrm{~cm}$ pada jantan dan $18,86 \pm 0,484 \mathrm{~cm}$ pada betina, maka hasil penelitian ini lebih rendah $3,2 \mathrm{~cm}$ pada jantan dan lebih tinggi $2,042 \mathrm{~cm}$ pada betina.

\section{Lebar Sayap}

Lebar sayap (LS) dimulai dari bagian atas sayap hingga bagian terbawa sayap (diukur bagian terlebar dari bentangan sayap). Dari Tabel 3 dapat dilihat lebar sayap (LS) rataan pada jantan 19,57 $\pm 2,507 \mathrm{~cm}$ dan pada betina $18,70 \pm 2,154 \mathrm{~cm}$.

\section{Lingkar Dada}

Lingkar dada (LiD) di ukur melingkar scapula menggunakan pita ukur. Dari Tabel 3 dapat dilihat lingkar dada (LiD) rataan pada jantan $30,77 \pm 5,268 \mathrm{~cm}$ dan pada betina 28,83 \pm $4,612 \mathrm{~cm}$.

\section{Lebar Dada}

Lebar dada (LeD) di ukur dari kiri ke kanan bagian depan dada menggunakan pita ukur. Dari Tabel 3 dapat dilihat lebar dada (LeD) rataan pada jantan 13,19 $\pm 2,138 \mathrm{~cm}$ dan pada betina $12,33 \pm 1,856 \mathrm{~cm}$.

\section{Panjang Kepala}

Panjang kepala (PK) di ukur pada posisi tengah kepala dari atas paruh hingga pangkal kepala belakang dengan jangka sorong. Dari Tabel 3 dapat dilihat panjang kepala (PK) rataan pada jantan $4,71 \pm 0,917 \mathrm{~cm}$ dan pada betina $4,11 \pm 0,738 \mathrm{~cm}$. 


\section{Lebar Kepala}

Lebar kepala (LK) di ukur dari posisi samping bagian kiri sampai kanan dengan menggunakan jangka sorong. Dari Tabel 3 dapat dilihat lebar kepala (LK) rataan pada jantan $3,40 \pm 0,552 \mathrm{~cm}$ dan pada betina $3,07 \pm 0,440 \mathrm{~cm}$.

\section{Panjang Paruh}

Panjang paruh (PP) di mulai dari pangkal sampai ujung paruh bagian atas di ukur menggunakan pita ukur. Dari Tabel 3 dapat dilihat panjang paruh (PP) rataan pada jantan $2,47 \pm 0,573 \mathrm{~cm}$ dan pada betina $2,24 \pm 0,479 \mathrm{~cm}$.

\section{Panjang Jengger}

Panjang jengger (PJ) di ukur dari posisi depan hingga akhir bagian jengger menggunakan pita ukur. Dari Tabel 3 dapat dilihat panjang jengger (PJ) rataan pada jantan $3,18 \pm 2,079 \mathrm{~cm}$ dan pada betina $1,67 \pm 0,998 \mathrm{~cm}$.

\section{Tinggi Jengger}

Tinggi jengger (TJ) di ukur dari pangkal jengger di atas kepala hingga bagian tertinggi jengger di ukur menggunakan pita ukur. Dari Tabel 3 dapat dilihat tinggi jengger (TJ) rataan pada jantan $1,77 \pm 2,219 \mathrm{~cm}$ dan pada betina $0,84 \pm 0,776 \mathrm{~cm}$. Bila dibandingkan dengan hasil penelitian Pecten Oculi Capilaries pada jantan 2,31 $\pm 1,144 \mathrm{~cm}$ dan pada betina $0,98 \pm 0,522 \mathrm{~cm}$, maka hasil penelitian ini labih rendah pada jantan maupun pada betina yaitu $0,54 \mathrm{~cm}$ dan $0,14 \mathrm{~cm}$.

\section{Panjang tulang Tibia}

Panjang tulang tibia (PtT) di ukur menggunakan pita ukur. Dari Tabel 3 dapat dilihat panjang tulang tibia (PtT) rataan pada jantan 12,69 $\pm 2,626 \mathrm{~cm}$ dan pada betina 11,21 \pm $2,097 \mathrm{~cm}$.

\section{Panjang Metatarsus}

Panjang metatarsus (PM) di ukur dari ujung tulang tibia hingga pangkal metatarsus bagian bawah di ukur menggunakan pita ukur. Dari Tabel 3 dapat dilihat panjang metatarsus (PM) rataan pada jantan $8,61 \pm 1,964 \mathrm{~cm}$ dan pada betina 7,18 $\pm 1,429 \mathrm{~cm}$. Bila dibandingkan 
dengan hasil penelitian Sisson dan Grossman (1953) pada jantan 10,36 \pm 1,448 cm dan pada betina $8,10 \pm 0,667 \mathrm{~cm}$, maka hasil penelitian ini lebih rendah pada jantan maupun betina $1,75 \mathrm{~cm}$ dan $0,92 \mathrm{~cm}$.

\section{Lingkar Metatarsus}

Lingkar metatarsus (LM) di ukur pada diameter menggunakan jangka sorong. Dari Tabel 3 dapat dilihat lingkar metatarsus (LM) rataan pada jantan 1,26 \pm 0,299 $\mathrm{cm}$ dan pada betina $1,05 \pm 0,261 \mathrm{~cm}$.

\section{Panjang jari Terpanjang}

Panjang jari terpanjang (PjT) dari ayam kampung menggunakan pita ukur. Dari Tabel 3 dapat dilihat panjang jari terpanjang $(\mathrm{PjT})$ rataan pada jantan $6,54 \pm 0,847 \mathrm{~cm}$ dan pada betina 5,88 $\pm 0,650 \mathrm{~cm}$. Bila dibandingkan dengan penelitian Kusnadidi dan Firda (2011) pada jantan 7,32 $\pm 0,835 \mathrm{~cm}$ dan pada betina $6,35 \pm 0,605 \mathrm{~cm}$. maka hasil penelitian ini lebih rendah pada jantan maupun pada betina $0,78 \mathrm{~cm}$ dan $0,47 \mathrm{~cm}$.

\section{Analisis Diskriminan pada Ayam Kampung}

Berdasarkan Gambar 6, ayam kampung jantan di kecamatan Sungai Kanan, kecamatan Kampung Rakyat, kecamatan Silangkitang dan kecamatan Kota Pinang terlihat mengelompok dan tersebar disebelah kiri sedangkan kecamatan Torgamba memperlihatkan penampilan fenotipik yang berbeda lebih menyebar kesebelah kanan bila dibandingkan dengan ayam kampung jantan di kecamatan yang lainnya.

Secara keseluruhan ayam kampung jantan berkumpul di sebelah kiri dengan banyaknya irisan antar kerumunan, hal ini menunjukkan tingkat persamaan antar ayam kampung jantan sangat tinggi dan berada pada populasi dan lingkungan yang tidak jauh berbeda, dan cara pemeliharaan tidak jauh beda atau bisa dikatakan sama.

Berdasarkan gambar dibawah, ayam kampung betina di kecamatan Sungai Kanan, kecamatan Kampung Rakyat, kecamatan Silangkitang dan kecamatan Kota Pinang meskupun terlihat mengelompok tapi Gambar 7 jauh lebih menyebar dibandingkan Gambar 6 . kecamatan Torgamba juga memperlihatkan penampilan fenotipik yang berbeda lebih menyebar kesebelah kanan dan ayam kampung betina menunjukkan hal yang sama dengan ayam kampung jantan Gambar 6 di Kecamatan yang lainnya 


\section{Analisis Morfometrik ayam}

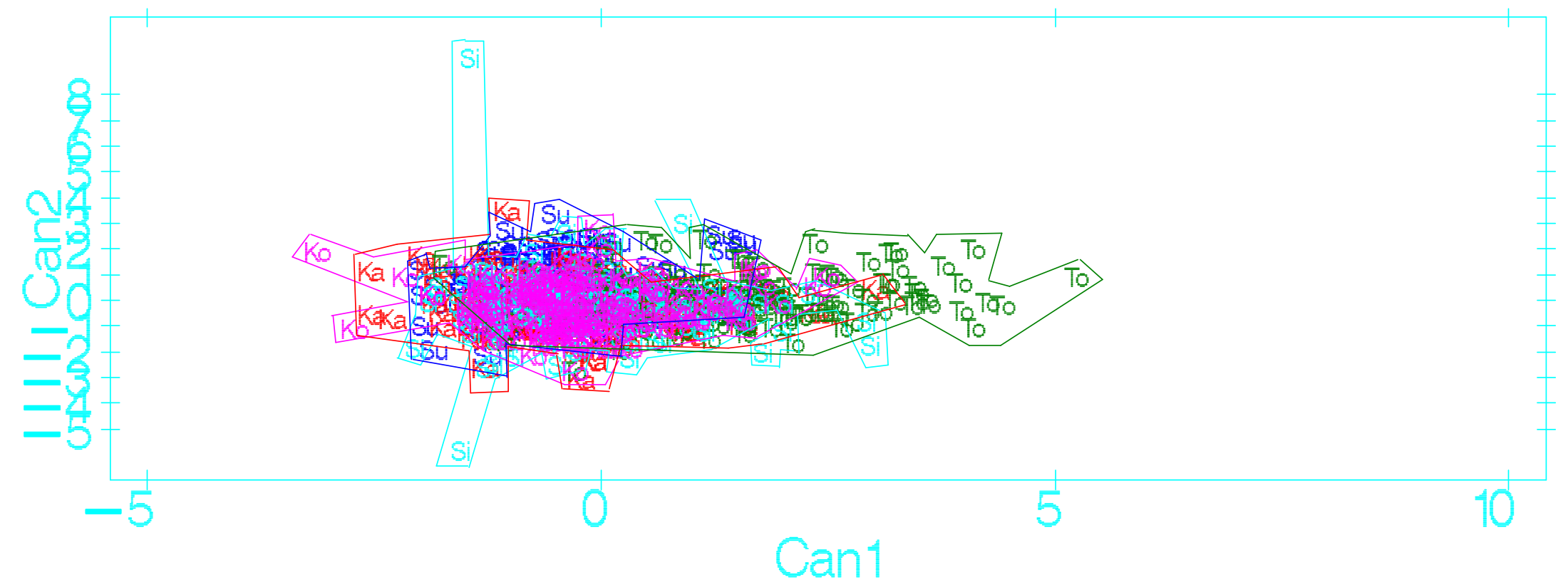

Gambar 6. Peta penyebaran ayam kampung jantan menurut ukuran fenotipik, ayam kampung jantan kecamatan Sungai Kanan (Su), kecamatan Kampung Rakyat (Ka), kecamatan Torgamba (To), kecamatan Silangkitang (Si), kecamatan Kota Pinang (Ko) 


\section{AnalisiS Morfometrik AYAM}

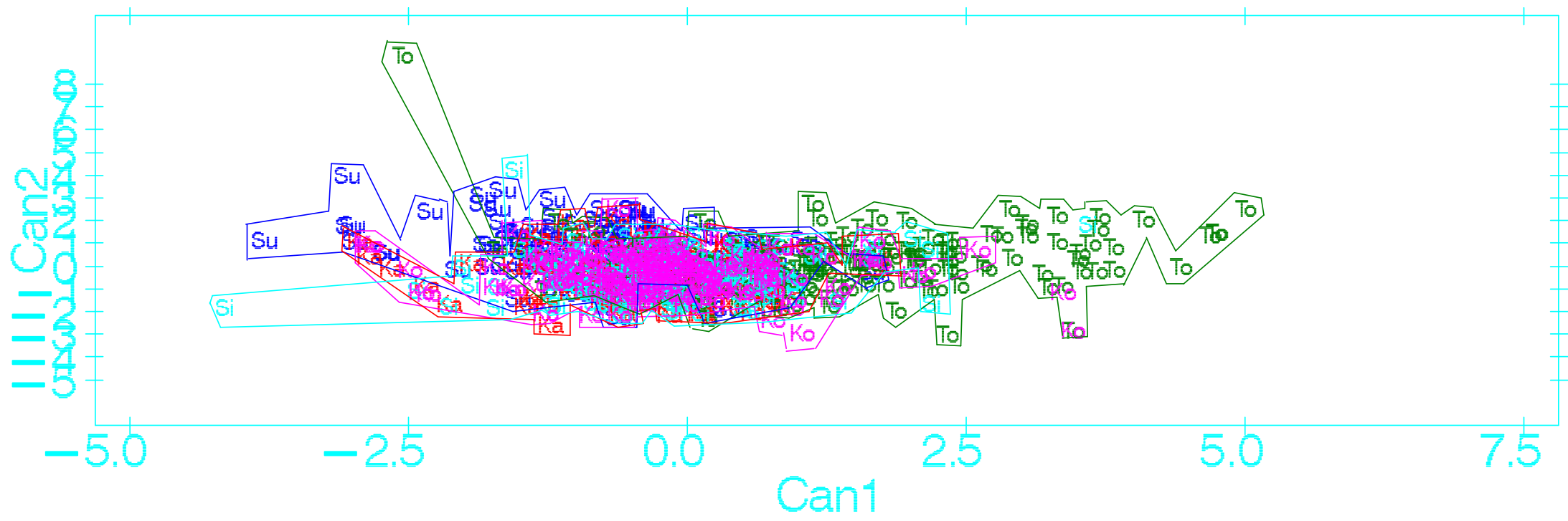

Gambar 7. Peta penyebaran ayam kampung jantan menurut ukuran fenotipik, ayam kampung betina kecamatan Sungai Kanan (Su), kecamatan Kampung Rakyat (Ka), kecamatan Torgamba (To), kecamatan Silangkitang (Si), kecamatan Kota Pinang (Ko) 


\section{Nilai Kesamaan dan Campuran antar Kecamatan pada Ayam Kampung}

Hasil analisis fungsi diskriminan terhadap karakteristik ukuran tubuh dari beberapa Kecamatan di Labuhanbatu Selatan pada ayam kampung menghasilkan pengelompokkan berdasarkan persentase nilai kesamaan dan campuran dapat dilihat pada Tabel 4 dan 5. Dari tabel tersebut dapat diduga adanya nilai kesamaan pada suatu Kecamatan dengan kemungkinan besarnya proporsi nilai campuran yang mempengaruhi kesamaan satu Kecamatan dengan Kecamatan lainnya di Labuhanatu Selatan berdasarkan atas persamaan karakteristik ukuran tubuh hasil pengelompokan ini juga menggambarkan persentase kemurnian setiap ayam kampung.

Tabel 4. Persentase nilai kesamaan dan campuran antar kecamatan pada ayam kampung jantan

\begin{tabular}{lllllll}
\hline \multicolumn{1}{c}{ Kecamatan } & $\begin{array}{l}\text { Sungai } \\
\text { Kanan }\end{array}$ & $\begin{array}{l}\text { Kampung } \\
\text { Rakyat }\end{array}$ & $\begin{array}{l}\text { Kota } \\
\text { Pinang }\end{array}$ & Silangkitang & Torgamba & Total \\
\hline Sungai Kanan & 47,75 & 19,66 & 8,99 & 15,17 & 8,43 & 100,00 \\
Kampung Rakyat & 27,37 & 19,47 & 16,32 & 19,47 & 17,37 & 100,00 \\
Kota Pinang & 27,42 & 19,35 & 21,51 & 13,44 & 18,28 & 100,00 \\
Silangkitang & 24,87 & 18,52 & 13,76 & 22,75 & 20,11 & 100,00 \\
Torgamba & 10,70 & 8,56 & 8,02 & 13,90 & 58,82 & 100,00 \\
Total & 27,42 & 17,10 & 13,76 & 16,99 & 24,73 & 100,00 \\
\hline
\end{tabular}

Tabel 5. Persentase nilai kesamaan dan campuran antar kecamatan pada ayam kampung betina

\begin{tabular}{lllllll}
\hline \multicolumn{1}{c}{ Kecamatan } & $\begin{array}{l}\text { Sungai } \\
\text { Kanan }\end{array}$ & $\begin{array}{l}\text { Kampung } \\
\text { Rakyat }\end{array}$ & $\begin{array}{l}\text { Kota } \\
\text { Pinang }\end{array}$ & Silangkitang & Torgamba & Total \\
\hline Sungai Kanan & 58,10 & 13,41 & 5,03 & 13,41 & 10,06 & 100,00 \\
Kampung Rakyat & 24,87 & 23,81 & 8,99 & 31,22 & 11,11 & 100,00 \\
Kota Pinang & 23,91 & 22,28 & 14,13 & 24,46 & 15,22 & 100,00 \\
Silangkitang & 18,72 & 17,65 & 14,44 & 34,22 & 14,97 & 100,00 \\
Torgamba & 8,90 & 5,24 & 7,85 & 14,66 & 63,35 & 100,00 \\
Total & 26,56 & 16,45 & 10,11 & 23,66 & 23,23 & 100,00 \\
\hline
\end{tabular}

Kesamaan ukuran tubuh dari beberapa Kecamatan di Kabupaten Labuhanbatu Selatan dari yang tinggi ke yang rendah berturut-turut, ukuran tubuh ayam kampung jantan pada kecamatan Torgamba 58,82\%, kecamatan Sumgai Kanan 47,75\%, kecamatan Silangkitang 22,75\%, kecamatan Kota Pinang 21,51\%, kecamatan Kampung Rakyat 19,47\%. Sedangkan ukuran tubuh ayam kampung betina pada kecamatan Torgamba 63,35\%, kecamatan Sungai Kanan 58,10\%, Kec. Silangkitang 34,22\%, kecamatan Kampung Rakyat 23,81\%, kecamatan Kota Pinang 14,13\%. 
Ayam kampung jantan pada kecamatan Torgamba karakteristik ukuran tubuh dipengaruhi oleh ayam kampung jantan kecamatan Silangkitang 13,90\%, kecamatan Sungai Kanan 10,70\%, kecamatan Kampung Rakyat 8,56\%, kecamatan Kota Pinang 8,02\%. Sedangkan ayam kampung betina pada kecamatan Torgamba juga dipengaruhi oleh kecamatan Silangkitang 14,66\%, kecamatan Sungai Kanan 8,90\%, kecamatan Kota Pinang 7,85\%, kecamatan Kampung Rakyat $5,24 \%$.

Karakteristik ukuran tubuh ayam kampung jantan pada kecamatan Sungai Kanan dipengaruhi oleh ayam kampung jantan di kecamatan Kampung Rakyat 19,66\%, kecamatan Silangkitang 15,17\%, kecamatan Kota Pinang 8,99\%, kecamatan Torgamba 8,43\%. Sedangkan ayam kampung betina pada kecamatan Sungai Kanan juga dipengaruhi oleh kecamatan Kampung Rakyat 13,41\%, kecamatan Silangkitang 13,41\%, kecamatan Torgamba 10,06\%, kecamatan Kota Pinang 5,03\%.

Hasil penelitian ayam kampung jantan pada kecamatan Silangkitang karakteristik ukuran tubuhnya dipengaruhi oleh ayam kampung jantan kecamatan Sungai Kanan 24,87\%, kecamatan Torgamba 20,11\%, kecamatan Kampung Rakyat 18,52\%, kecamatan Kota Pinang 8,02\%. Sedangkan ayam kampung betina pada kecamatan Sungai Kanan juga dipengaruhi oleh kecamatan Sungai Kanan 18,72\%, kecamatan Kampung Rakyat 17,65\%, kecamatan Torgamba $14,97 \%$, kecamatan Kota Pinang 14,44\%.

Ayam kampung jantan pada kecamatan Kota Pinang karakteristik ukuran tubuhnya dipengaruhi oleh ayam kampung jantan kecamatan Sungai Kanan 27,42\%, kecamatan Kampung Rakyat 19,35\%, kecamatan Torgamba 18,28\%, kecamatan Silangkitang 13,44\%. Sedangkan ayam kampung betina pada kecamatan Kota Pinang juga dipengaruhi oleh kecamatan Silangkitang 24,46\%, kecamatan Sungai Kanan 23,91\%, kecamatan Kampung Rakyat 22,28\%, kecamatan Torgamba 15,22\%.

Pada kecamatan Kampung Rakyat karakteristik ukuran tubuh ayam kampung jantan dipengaruhi oleh ayam kampung jantan kecamatan Sungai Kanan 27,37\%, kecamatan Silangkitang 19,47\%, kecamatan Torgamba 17,37\%, kecamatan Kota Pinang 16,32\%. Sedangkan ayam kampung betina pada kecamatan Kampung Rakyat juga dipengaruhi oleh jantan kecamatan Silangkitang 31,22\%, kecamatan Sungai Kanan 24,87\%, kecamatan Torgamba $11,11 \%$, kecamatan Kota Pinang 8,99\%. 
Nilai kesamaan dan campuran antar kecamatan pada ayam kampung jantan yang paling tinggi adalah ayam kampung jantan di kecamatan Sungai Kanan dan kecamatan Kota Pinang 27,42\%, sedangkan yang paling rendah pada kecamatan Kota Pinang dan Kec. Torgamba 8,02\%. Nilai kesamaan dan campuran antar kecamatan Pada ayam kampung betina yang paling tinggi adalah ayam kampung betina di kecamatan Sungai Kanan dan kecamatan Kampung Rakyat $24,87 \%$, sedangkan yang paling rendah pada kecamatan Kota Pinang dan kecamatan Sungai Kanan 5,03\%.

\section{Jarak Genetik}

Tabel 6. Jarak genetik antar kecamatan ayam kampung jantan.

\begin{tabular}{lccccc}
\hline \multicolumn{1}{c}{ Kecamatan } & $\begin{array}{c}\text { Sungai } \\
\text { Kanan }\end{array}$ & $\begin{array}{c}\text { Kampung } \\
\text { Rakyat }\end{array}$ & $\begin{array}{c}\text { Kota } \\
\text { Pinang }\end{array}$ & Silangkitang & Torgamba \\
\hline Sungai Kanan & 0 & & & & \\
Kampung Rakyat & 0,49259 & 0 & & & \\
Kota Pinang & 0,50703 & 0,04818 & 0 & & \\
Silangkitang & 0,51930 & 0,12588 & 0,14370 & 0 & \\
Torgamba & 2,73670 & 2,29210 & 1,99289 & 2,08874 & 0 \\
\hline
\end{tabular}

Nilai jarak genetik ayam kampung dari beberapa Kecamatan di Kabupaten Labuhanbatu Selatan dapat dilihat pada Tabel 6 digunakan untuk membuat konstruksi pohon fenogram (Gambar 8). Pohon fenogram menggambarkan jarak genetik keseluruhan antara ayam kampung. Berdasarkan nilai jarak genetiknya, ayam kampung jantan memiliki nilai yang terkecil yaitu kecamatan Kampung Rakyat dan kecamatan Kota Pinang 0,04818, kecamatan Kampung Rakyat dan kecamatan Silangkitang 0,12588, kecamatan Kota Pinang dan kecamatan Silangkitang 0,14370, kecamatan Sungai Kanan dan kecamatan Kampung Rakyat 0,49259, kecamatan Sungai Kanan dan kecamatan Kampung Rakyat 0,50703, kecamatan Sungai Kanan dan kecamatan Kota Pinang 0,51930, selanjutnya nilai yang tertinggi terdapat pada kecamatan Kota Pinang dan kecamatan Torgamba 1,99289, kecamatan Silangkitang dan kecamatan Torgamba 2,08874, kecamatan Kampung Rakyat dan kecamatan Torgamba 2,29210 kecamatan Sungai Kanan dan kecamatan Torgamba 2,73670.

Tabel 7. Jarak genetik antar kecamatan ayam kampung betina.

\begin{tabular}{llllll}
\hline Kecamatan & Sungai & Kampung & Kota & Silangkitang & Torgamba \\
\hline
\end{tabular}




\begin{tabular}{lccccc}
\hline & Kanan & Rakyat & Pinang & & \\
\hline Sungai Kanan & 0 & & & & \\
Kampung Rakyat & 0,91932 & 0 & & & \\
Kota Pinang & 1,00379 & 0,09265 & 0 & 0 & \\
Silangkitang & 1,17142 & 0,06920 & 0,10930 & 0 \\
Torgamba & 3,47529 & 2,37113 & 2,10407 & 2,15515 & 0 \\
\hline
\end{tabular}

Kecamatan di Kabupaten Labuhanbatu Selatan nilai jarak genetik ayam kampung dapat dilihat pada Tabel 7 digunakan untuk membuat konstruksi pohon fenogram (Gambar 9). Pohon fenogram menggambarkan jarak genetik keseluruhan antara ayam kampung. Berdasarkan nilai jarak genetiknya, ayam kampung betina memiliki nilai yang terkecil yaitu kecamatan Kampung Rakyat dan kecamatan Silangkitang 0,06920, kecamatan Kampung Rakyat dan kecamatan Kota Pinang 0,09265, kecamatan Kota Pinang dan kecamatan Silangkitang 0,10930, kecamatan Sungai Kanan dan kecamatan Kampung Rakyat 0,91932, selanjutnya nilai yang tertinggi terdapat pada kecamatan Sungai Kanan dan kecamatan Kota Pinang 1,00379, kecamatan Sungai Kanan dan kecamatan Silangkitang 1,17142, kecamatan Kota Pinang dan kecamatan Torgamba 2,10407, kecamatan Silangkitang dan kecamatan Torgamba 2,15515, kecamatan Kampung Rakyat dan kecamatan Torgamba 2,37113, kecamatan Sungai Kanan dan kecamatan Torgamba 3,47529 .

\section{Pohon Fenogram Ayam Kampung}

Pohon fenogram ayam kampung jantan (Gambar 8) pada kecamatan Kampung Rakyat lebih dekat dengan yang di kecamatan Kota Pinang, kecamatan Silangkitang dan kecamatan Sungai Kanan. Hal ini disebabkan angka jarak genetik (nilai kesamaan dan campuran) antara kecamatan Kampung Rakyat dengan kecamatan Kota Pinang, kecamatan Silangkitang dan kecamatan Sungai Kanan sehingga membentuk hubungan kekerabatan yang cukup dekat. 


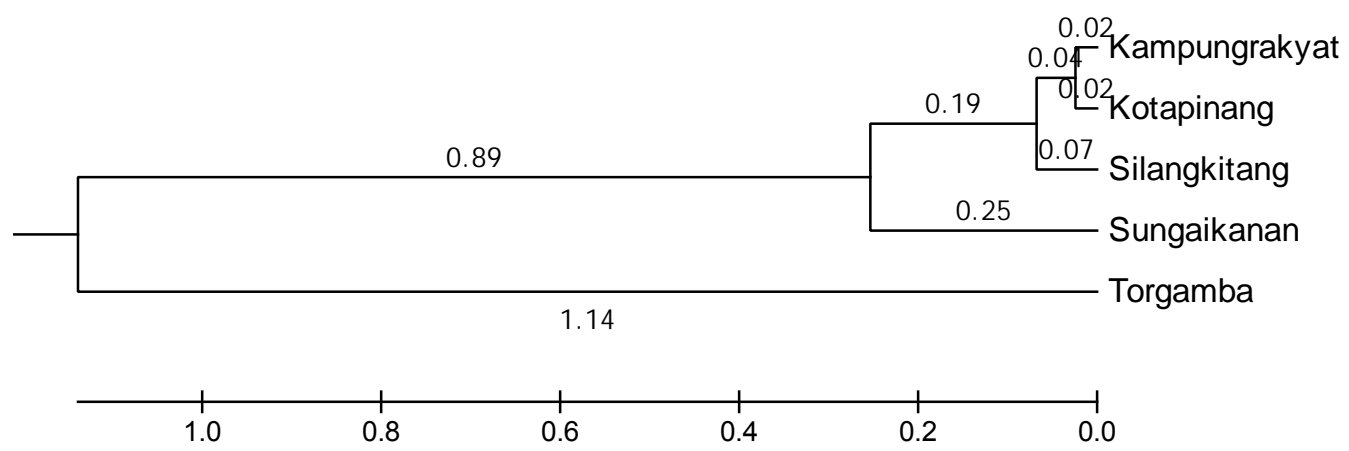

Gambar 8. Pohon fenogram ayam kampung jantan.

Hasil penelitian pohon fenogram ayam jantan (Gambar 8) kecamatan Torgamba menunjukkan garis yang berbeda dengan kecamatan Kampung Rakyat, kecamatan Kota Pinang, kecamatan Silangkitang dan kecamatan Sungai Kanan yang mengartikan hubungan kekerabatan ayam jantan kecamatanTorgamba dengan ayam kampung jantan lainnya cukup jauh berdasarkan ukuran dan bentuk tubuh, hal ini dipengaruhi tingginya nilai kesaaman dan tidak adanya campuran galur lain terhadap kecamatan Torgamba. secara genetik kecamatan Torgamba bertipe kecil sedangkan kecamatan Kampung Rakyat, kecamatan Kota Pinang, kecamatan Silangkitang dan kecamatan Sungai Kanan bertipe besar menandakan berbeda secara genetik sehingga jarak genetiknya relatif jauh, jarak genetik kecamatan Torgamba dengan kecamatan Sungai Kanan adalah 2,73670 sedangkan kecamatan Torgamba dengan kecamatan Kampung Rakyat 2,29210. Untuk galur kecamatan Torgamba jika disilangkan dengan kecamatan Sungai Kanan atau kecamatan Kampung Rakyat dapat diperoleh peningkatan ukuran tubuh dikarenakan jauhnya jarak genetik tersebut.

Hasil penelitian ayam kampung betina pohon fenogram (Gambar 9) pada kecamatan Kampung Rakyat lebih dekat dengan yang di kecamatan Silangkitang, kecamatan Kota Pinang, dan kecamatan Sungai Kanan. Hal ini disebabkan angka jarak genetik (nilai kesamaan dan campuran) antara kecamatan Kampung Rakyat dengan kecamatan Silangkitang, kecamatan Kota Pinang, dan kecamatan Sungai Kanan sehingga membentuk hubungan kekerabatan yang cukup dekat.

Pohon fenogram ayam kampung betina (Gambar 9) kecamatan Torgamba menunjukkan garis yang berbeda dengan kecamatan Kampung Rakyat, kecamatan Silangkitang, kecamatan Kota Pinang, dan kecamatan Sungai Kanan yang mengartikan hubungan kekerabatan ayam 
kampung betina kecamatan Torgamba dengan ayam kampung betina lainnya cukup jauh berdasarkan ukuran dan bentuk tubuh, hal ini dipengaruhi tingginya nilai kesaaman dan tidak adanya campuran galur lain terhadap kecamatan Torgamba. Secara genetik kecamatan Torgamba bertipe kecil sedangkan Kec. Kampung Rakyat, kecamatan Silangkitang, kecamatan Kota Pinang, dan kecamatan Sungai Kanan bertipe besar menandakan berbeda secara genetik sehingga jarak genetiknya relatif jauh, jarak genetik kecamatan Torgamba dengan kecamatan Sungai Kanan adalah 3,47529 sedangkan kecamatan Torgamba dengan kecamatan Kampung Rakyat 2,37113. Untuk galur kecamatan Torgamba jika disilangkan dengan kecamatan Sungai Kanan atau kecamatan. Kampung Rakyat dapat diperoleh peningkatan ukuran tubuh dikarenakan jauhnya jarak genetik tersebut.

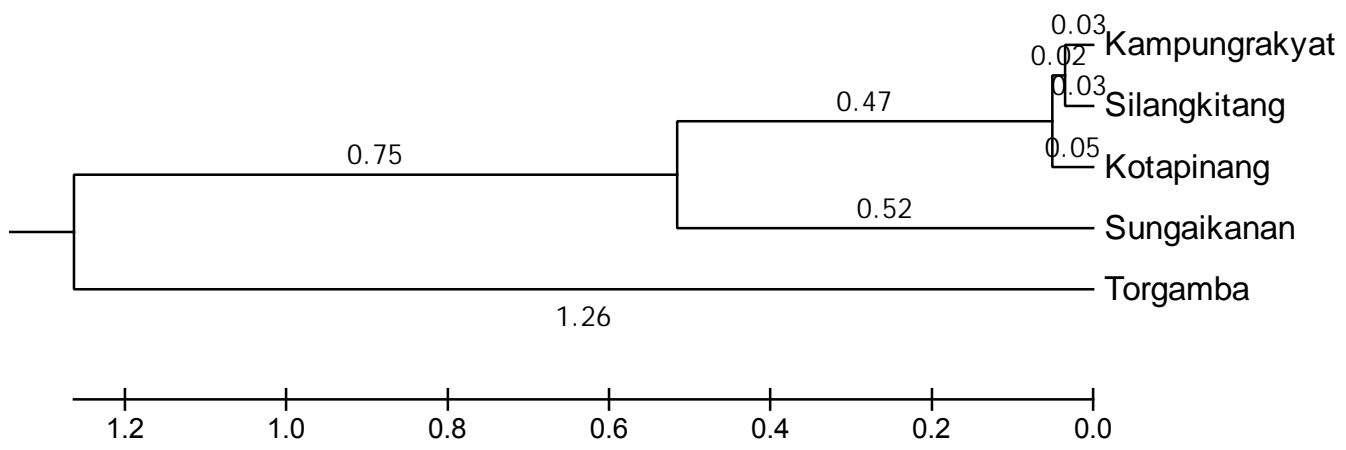

Gambar 9. Pohon fenogram ayam kampung betina.

\section{Peubah Pembeda Ayam Kampung}

Analisis variat kanonikal (Tabel 8) digunakan untuk mendapatkan kombinasi karakter yang membedakan secara keseluruhan dan dapat digunakan untuk menggambar plot skor guna membandingkan di dalam dan diantara variabilitas populasi (ayam kampung) pada dimensi yang kecil (Wiley,1981).

Kanonik 1 ayam kampung jantan diperoleh korelasi cukup tinggi pada parameter Panjang Leher (0,512802), dan Lingkar Dada (0,463822). Pada kanonik 2 ayam kampung jantan diperoleh Panjang Paruh (0,316158), dan Panjang Jengger (0,274712), dengan demikian peubah Panjang Leher, Lingkar Dada, Panjang Paruh dan Panjang Jengger dapat digunakan sebagai peubah pembeda antar ayam kampung jantan. 
Kanonik 1 ayam kampung betina diperoleh korelasi cukup tinggi pada peubah Lebar Sayap (0,537195), dan Panjang Badan (0,483434). Pada kanonik 2 ayam kampung betina diperoleh Panjang Paruh (0,599834), Panjang Jengger (0,443942), dengan demikian peubah Lebar Sayap, Panjang Badan, Panjang Leher, Panjang Metatarsus, Panjang Sayap, Lingkar Dada, Panjang Kepala, Panjang Paruh dan Panjang Jengger dapat digunakan sebagai peubah pembeda antar ayam kampung betina.

Table 8. Total struktur kanonikal.

\begin{tabular}{lcccc}
\hline \multicolumn{1}{c}{ Parameter } & $\begin{array}{c}\text { KAN 1 } \\
\text { Jantan }\end{array}$ & $\begin{array}{c}\text { KAN 2 } \\
\text { Jantan }\end{array}$ & $\begin{array}{c}\text { KAN 1 } \\
\text { Betina }\end{array}$ & $\begin{array}{c}\text { KAN 2 } \\
\text { Betina }\end{array}$ \\
\hline Panjang Badan & 0,301204 & $-0,338365$ & 0,483434 & $-0,015407$ \\
Panjang Leher & 0,512802 & $-0,361840$ & 0,455092 & 0,109295 \\
Panjang Sayap & 0,277999 & $-0,285503$ & 0,443395 & 0,025013 \\
Lebar Sayap & 0,454226 & $-0,140519$ & 0,537195 & 0,112510 \\
Lingkar Dada & 0,463822 & $-0,273139$ & 0,436602 & $-0,022532$ \\
Lebar Dada & $-0,152611$ & $-0,265277$ & $-0,239794$ & $-0,075122$ \\
Panjang Kepala & 0,374332 & $-0,189825$ & 0,430628 & $-0,014924$ \\
Lebar Kepala & 0,064375 & $-0,398279$ & 0,148197 & $-0,066891$ \\
Panjang Paruh & 0,310460 & 0,316158 & 0,165762 & 0,599834 \\
Panjang Jengger & 0,023344 & 0,274712 & $-0,020499$ & 0,443942 \\
Tinggi Jengger & $-0,033769$ & 0,079901 & $-0,058344$ & 0,248591 \\
Panjang tulang Tibia & 0,342259 & $-0,196540$ & 0,230875 & 0,033290 \\
Panjang Metatarsus & 0,400371 & $-0,062138$ & 0,444312 & 0,101268 \\
Lingkar Metatarsus & 0,372159 & $-0,246150$ & 0,396819 & 0,045346 \\
Panjang jari Terpanjang & 0,113546 & $-0,366748$ & 0,328748 & $-0,308549$ \\
\hline
\end{tabular}

\section{KESIMPULAN}

Penampilan fenotip berdasarkan analisis morfometrik menunjukkan perbedaan secara morfologi pada setiap ayam kampung, dari 5 kecamatan yang ada di Labuhanbatu Selatan, ayam 
kampung di kecamatan Torgamba secara fenotipik berbeda dengan ayam kampung yang di kecamatan Sungai Kanan, kecamatan Silangkitang, kecamatan Kota Pinang dan kecamatan Kampung Rakyat dimana jumlah ukuran tubuh lebih besar dibandingkan ayam kampung lain. Analisis kanonik fenotipik pembeda ayam kampung adalah Lebar Sayap, Panjang Badan, Panjang Leher, Lingkar Dada, Panjang Paruh dan Panjang Jengger dapat digunakan sebagai peubah pembeda antar ayam kampung betina.

Berdasarkan nilai kesamaan dan campuran dalam antar kecamatan yang tertinggi terdapat pada kecamatan Torgamba 58,82\% pada ayam kampung jantan dan 63,35\% pada ayam kampung betina. Jarak genetik ayam kampung tertinggi terdapat di kecamatan Torgamba dan kecamatan Sungai Kanan yaitu 2,73670 pada jantan dan 3,47529 pada betina, hal tersebut membuktikan selama ini terjadi persilangan antar ayam kampung dan dengan tujuan produksi yaitu sebagai ternak konsumsi sehari - hari dan ternak hias. Peneliti menyarankan agar pengukuran organ tubuh ayam kampung dilakukan dengan parameter yang lebih banyak. Ayam kampung jantan di kecamatan Kampung Rakyat dan kecamatan Kota Pinang sebaiknya diseleksi sedangkan ayam kampung jantan yang di kecamatan Torgamba dan kecamatan Kampung Rakyat sebaiknya disilangkan, ayam kampung betina di kecamatan Kampung Rakyat dan kecamatan Silangkitang sebaiknya diseleksi, sedangkan ayam kampung betina yang di kecamatan Kampung Rakyat dan kecamatan Torgamba sebaiknya disillangkan.

\section{DAFTAR PUSTAKA}

Kurniawati, A. 2008. Ukuran dan Bentuk Tubuh Ayam Arab, Ayam Kampung dan Ayam Pelung Berdasarkan Analisis Komponen Utama. Skripsi. Institut Pertanian Bogor.

Chen, L. F., Y. P. Lee., Z. H. Lee., S. Y. Huang and H. H. Huang. 1993. Heritability and genetic correlation of egg quality traits in Taiwan,s local chickens. AJAS Journal 6 (3): 433-440.

McLelland, J. 1990. A Colour Atlas of Avian Anatomy. Wolfe Publishing Ltd., London.

Mulliono, R.H. dan Pangestu, R.B. 1996. Analisis statistik Ukuran- Ukuran Tubuhdan Analisis Karakter- Karakter Genetk Eksternal pada Ayam Kampung, Ayam Pelung dan Ayam Kedu. Laporan Penelitian. Fakultas Peternakan. Institut Pertanian Bogor.

Nataamijaya, A. G. 2000. The native chicken of Indonesia. Bulletin Plasma Nutfah VI (1): 1-6. 
Nishida, T. K. Nozawa. Y. Hayasi. T. Hashiguchi and S.S. Mansjoer.1982. Body measurement and analis on exsternal genetic characters of Indonesian native fowl. The Origin and Phylogeny of Indonesian Native Livestock. III :73-83.

Romdhani, S. 2004. Face Rekognition using Prinsipal Component Analysis. http:// www. Elec. Gla.ac. uk-romdhani.

SAS. 1985. Statistic Analytical System. SAS/STAT Guide for Personal Computer. Ver. 6.12. SAS Institute Inc. Cary, N.C.

Sisson, S and J. D. Grossman. 1953. The Anatomy of the Domestic Animals. 4th Revised Edition. W. B. Saunders Company, Philadelphia

Sulandari, S., M. S. A. Zein., S. Paryanti, T. Sartika, M. Astuti, T. Widjastuti, E. Sudjana, S. Darana, I. Setiawan dan D. Garnida. 2007. Sumberdaya genetik ayam lokal Indonesia. Keanekaragaman Sumberdaya Hayati Ayam Lokal 50 Indonesia: Manfaat dan Potensi. Pusat Penelitian Biologi Lembaga Ilmu Pengetahuan Indonesia, Jakarta. Hal : 45-67.

Wiley, E. O. 1981. Phylogenetics: The Theory and Practice of Phylogenetic Systematics. Jhon Wiley \& Sons Inc. Canada. 